\title{
The effects of 8 week exercise program on reaction time performance of hearing impaired students at 11-14 years of age
}

\author{
Mehmet Özdemir ${ }^{1}$, Halil Tanır²a, Mehmet Ilkım³, and Murat Özmaden² \\ ${ }^{1}$ Physical Education and Sport High School, Bingöl University, Turkey. \\ ${ }^{2}$ Physical Education and Sport High School, Adnan Menderes University, Turkey. \\ ${ }^{3}$ Physical Education and Sport High School, Inonu University, Turkey.
}

\begin{abstract}
This research is aiming to investigate the effects of 8-week exercise program on reaction time performance of hearing impaired students at $11-14$ years of age. 32 students ( $n=16$ girls and $n=16$ males) aged between 11-14 years in the Malatya Akşemseddin Secondary School for Hearing Impaired Students were participated in the study by the consent of their parents. The students were divided into 2 groups as athletes ( $n=8$ girls and $n=8$ boys) and sedantary students $(n=8$ girls and $n=$ 8 boys). The athlete students are engaged in activities like "Turning to the front with the basketball ball with the ball and taking the pass, walking on the balance instrument which is $30 \mathrm{~cm}$ wide and $3 \mathrm{~m}$ long, making slight left and right bounces, $10 \mathrm{~m}$ short distance runnings, short distance rusting with a handball ball, throwing the basketball ball up about $2 \mathrm{~m}$ with a light, Sedantery students have not been subjected to any work during this period. The reaction time performances of all students participating in the 8 week were determined before and after workout program by the REACTION TIME HUBBARD - HAP brand device. It was determined that there was a significant difference between athletes and sedentary students in favor of the athletes in terms of pre-test and post-test results according to reaction time performance $(\mathrm{p}<0.05)$.To sum up it was found that the exercise program which was done for 3 days a week for 8 weeks, enhanced the reaction performance of hearing-impaired students aged 11-14 years.
\end{abstract}

Key Words: Hearing impaired students, reaction time, exercise

\section{Introduction}

There is more evidence that physical activity is beneficial to health and well-being, and it has a growing role in our life. It is suggested by some researchers that, regular physical exercises increase the physical and functional capacities of children as providing a strong and sheltered structure to the body. Sport is one of the best methods for social integration of disabled people. It also contributes to people's independence [16]. It is the most important factor that causes the disabled person to look at his life from different windows.

Today, sport is regarded as activities that are natural rather than leisure time sociology, and which should be done for the health of the individual in all fields. In addition to the supportive benefits of sports in the field of biological, psychological and social development, there is an encouraging aspect of belonging to a group and participating in group activities. Many studies show that the risk of heart disease in physically active individuals is lower than the sedentary ones $[8,9]$.

\footnotetext{
${ }^{\mathrm{a} C}$ Corresponding author:halil.tanir@adu.edu.tr
} 
Reaction time is one of the topics that scientists have been most interested in since the mid19 th century. Reaction time is defined as the period of preparation required to occur the movement by taking the stimulus $[1,17]$.The reaction time as the internal timing between the taking of the stimulus and the response [22]. The movement time is the time from the beginning to the end of the movement right after the reaction time [22, 19]. Reaction time is a positive effect of the organ systems, with the nervous system working regularly and coordinated work among the muscle groups [20].It is accepted that the reaction time can be shortened by training but it cannot be lowered to a certain level [11]. When examining the reaction time, it is necessary to distinguish the response time [19].The reaction time is considered to be a part of the reaction period in the true sense and the response time is the reaction time and the action time $[3,19]$. Some researchers have suggested that speed is a factor lying under reaction and movement time. [10,19].Reaction time is a decisive factor in most sports and can be improved by regular training. Because the reaction time seen as the main component of many skills [18]. It has been reported in many studies that regular training in a given program, can improve the reaction time [4,7 and 15].

\section{Methot}

\subsection{Participations}

It is aimed in the study that, the effect exercise on reaction times of hearing impaired students aged between 11-14 years. A total of 32 students, 16 male and 16 female, who studying at the Malatya Private Anatolian Private School participated as volunteer in the study with permission of their parents.

\subsection{Exercise Programme and Reaction Time Measurement}

To the participated 8 students of each group of male and female, simple attention enhancing actions such as; turn back based on turnover and do chest pass with basketball ball, walking on the balance instrument which is $40 \mathrm{~cm}$ high, $30 \mathrm{~cm}$ wide and $3 \mathrm{~m}$ long from the ground (each athlete made 4 trials) slightly left and right jumps, $10 \mathrm{~m}$ short distance start runs, short distance passes with handball ball, throw and keep the basketball ball up about $2 \mathrm{~m}$ with the lighted sign, were applied during eight weeks and three days in a week as Tuesday, Thursday and Saturday. The reaction times of the groups were measured before and after eight weeks of exercise with the REACTION TIME HUBBARD-HAP brand reaction meter. In the measurements, the best rating was recorded by giving three trials in the form of a light reaction in the hand-held reaction device of the hearing-impaired students.

Hearing-impaired students were identified in the Private Anatolian Private Education School (in the same school). Among the identified students, hearing-impaired students athletes and sedentary were identified. Students between the ages of 11-14 were participated. Eight students were identified in all groups (hearing-impaired students doing sports, hearing-impaired students not doing sports). Female and male students were evaluated among themselves. Sports groups were trained 3 days a week (Tuesday, Thursday, and Saturday). The study continued for 8 weeks. All groups were subjected to a reaction test with the REACTION TIME HUBBARD-HAP brand instrument before the study began and the results of these measurements were recorded. The reaction test was conducted in all groups over the hands of the students they used more frequently in daily life. Trainings such as; turn back based on turnover and do chest pass with basketball ball, walking on the balance instrument which is $40 \mathrm{~cm}$ high, $30 \mathrm{~cm}$ wide and $3 \mathrm{~m}$ long from the ground (each athlete made 4 trials) slightly left and right jumps, $10 \mathrm{~m}$ short distance start 
runs, short distance passes with handball ball, throw and keep the basketball ball up about $2 \mathrm{~m}$ with the lighted sign, were applied to the hearing impaired students during eight weeks. Nothing was applied to the students who did not do sports and their measurements were taken again after 8 weeks. Reaction measurements of hearing impaired students who, do sports and did not do sports, were taken again after 8 weeks by the same methods. Measurements of hearing-impaired students who do sports were taken before training day. Measurements were taken by putting out the light that appears in the reaction tool by hand, which students used in daily life. Initial measurements and final measurements of all students were taken on equal terms and in the same environment. In all measurements, each student has 3 trials and the best recorded as the result. The results of the hearing-impaired students who do sports were taken into account between themselves and the results of hearing-impaired students who did not do sports were taken into account between themselves.

\subsection{Exercise Programme and Reaction Time Measurement}

SPSS 22.0 (SPSS 22.0 for Windows / SPSS® Inc, Chicago, USA) was used for the statistical analysis of the data. The Paired-Sample $t$ test was used to compare the hearingimpaired students' differences according to the pre-test and post-test scores. A $p<0.05$ value was considered statistically significant.

\subsection{Statistical Analysis}

The sample of the study consists of 60 athletes $(n=30$ experimental group and $n=30$ control group) in the Malatya Sessiz Adımlar Sports Club, aged between 13 and 15, dealing with athleticism. Athletes in the experimental group were subjected to a training program to improve the balance and flexibility of 2 hours of 3 days a week for 8 weeks. The athletes in the control group continued their usual training programs. Before and after the 8 -week training program that is applicated for the athletes in the experimental group, the balance and flexibility performances of the athletes in both the experimental and control groups were determined. The following measurements were made to determine some physical and motoric characteristics of the athletes forming the sample.

\section{Findings}

Table 1. Descriptive Statistics of Subjects

\begin{tabular}{|l|l|c|c|}
\hline \multicolumn{2}{|l|}{ Variables } & $\mathbf{n}$ & $\mathbf{\%}$ \\
\hline \multirow{3}{*}{ Gender } & Female & 16 & 50 \\
\cline { 2 - 4 } & Male & 16 & 50 \\
\hline \multirow{3}{*}{ Athlete } & Total & $\mathbf{3 2}$ & $\mathbf{1 0 0}$ \\
\hline & Yes & 16 & 50 \\
\cline { 2 - 4 } & No & 16 & 50 \\
\hline & Total & $\mathbf{3 2}$ & $\mathbf{1 0 0}$ \\
\hline
\end{tabular}

In Table 1, descriptive statistics of the gender and athlete are shown. 
Table 2. Descriptive Statistics of Student's Some Anthropometric Characteristics

\begin{tabular}{|l|c|c|c|c|c|}
\hline Variables & Minimum & Maximum & $\mathbf{X}$ & Sd & Median \\
\hline Height (cm) & 1.38 & 1.74 & 1.53 & 0.08 & 1.51 \\
\hline Weight (kg) & 36 & 65 & 47.7 & 8.39 & 45.5 \\
\hline BMI (kg/m²) & 14.6 & 25.8 & 20.2 & 0.50 & 20.4 \\
\hline
\end{tabular}

In Table 2, According to the statistical values obtained from some anthropometric measurements of the subjects participated in the study, the height mean $1.51 \mathrm{~cm}$, weight mean 45.5 and body mass index means were determined as 20.4. The number of observations for all parameters is 32 .

Table 3. Comparison of Pre-test and Post-test Values of Athlete and Non-Athlete Subjects

\begin{tabular}{|l|c|c|c|c|c|c|c|c|}
\hline \multirow{2}{*}{ Groups } & \multicolumn{3}{|c|}{ Pre-test } & \multicolumn{3}{c|}{ Post-test } & \multicolumn{2}{c|}{ T test } \\
\cline { 2 - 9 } & $\mathbf{n}$ & $\mathbf{X}$ & Sd & $\mathbf{n}$ & $\mathbf{X}$ & Sd & t & P \\
\hline Athlete & 16 & 33.5 & 5.03 & 16 & 27.19 & 4.11 & 5.614 & $0.000^{*}$ \\
\hline Non-Athlete & 16 & 51.13 & 17.78 & 16 & 57.13 & 18.68 & -1.798 & 0.092 \\
\hline
\end{tabular}

* Significant level of 0.05 .

When Table 3 is examined, although there is a statistically significant difference between pre-test values and post-test values of athletes $(p<0.05)$; it is seen that there is no statistically significant difference between pre-test values and post-test values of nonathlete subjects $(\mathrm{p}>0.05)$

\section{Discussion and conclusion}

Because of hearing impaired people have little or no sense of hearing, late development of balance and motor skills negatively affects their interaction with their peers. Hearing impaired individuals suffer from inadequacy of balance and motor response due to insufficiency of sensory stimulation due to damage to hearing sensation. Physical activity is beneficial for development of balance and motor skills [13].

Simple reaction times of visually impaired individuals participating in regular physical exercises can reach much better levels than non-exercise visually impaired individuals. The reason for this situation is thought as; besides the development of the muscle-nerve conduction ability which is important in the reaction time through the training of the individuals participating in the physical exercises, to be a lack of experience, by gaining the skill on the forms of movement that are revealed by the activities carried out [2].

Cağlar et al. [5] specified, in their study about physical fitness of hearing impaired individuals who are athletes or non-athletes, that; there is significant differences between athletes and non-athletes regarding their, height, resting pulse, elasticity, stretching, $20 \mathrm{~m}$ speed, reaction time, hand grip strength, back and leg strength, shuttle, vertical jump and body fat percentage values $(\mathrm{p}<0.05)$.

In the study which made by Cigerci et al. [6] it was stated that; while there were significant differences when hearing-impaired sedentary men and non-hearing impaired sedentary men compared according to the reaction time values of right and left handed light 
$(p<0.05)$, there were no significant differences between hearing-impaired volleyball player men and non-hearing impaired volleyball player men, and hearing-impaired sedentary girls and non-hearing impaired sedentary girls $(p>0.05)$. It is seen that the results are similar because the content of the work we have done is close to each other with this study is.

Çağlar et al. [5] specified, in their study about hearing impaired individuals who are athletes or non-athletes, that; there is significant differences between active athletes and non-athlete's reaction time values. Similarly, Karagöz [12] notes in his master's thesis that 12-week training has significantly improved reaction times among children in the 8-10 age group. The limited literature we obtained as a result of the researches carried out supports our research results and specify that according to hearing impaired individuals participating in sports activities, the hearing impaired individuals who do not participate in sports activities have shorter reaction times. Participation in sports or physical exercise has a positive effect on the physical and motor development of the disabled, as it is in unimpeded individuals. Sirinkan [21] reports that sportive educational games applied to hearingimpaired students contribute to their physical development in the study he made about impact on the physical development of sportive educational games on 10-15 year old hearing impairment students. It is reported that; individuals who regularly participate in the physical activity program have higher physical capacity than sedentary individuals of the same age and that the nervous system responses are faster.

Bakır and Doğan [2].reports in their study that, there is a significant difference in favor of participated in sport sight-disabled individuals in terms of auditory simple reaction times between the sight-disabled and non-sported sight-disabled individuals $(\mathrm{p}<0.05)$. Çağlar at al. [5].reports as a result of their study that; sportive activity contributes significantly to physical development, physical fitness characteristics and body composition of hearingimpaired individuals.

It has been determined that the sport contributes significantly to physical development, physical fitness characteristics and body composition of hearing-impaired [5]. In our study, although there was a statistically significant difference between pre-test values and post-test values of athletes $(p<0.05)$, it is stated that there is no statistically significant difference between pre-test values and post-test values of non-athlete subjects (Table 3, $p>0.05$ ). Our study is similar with the study made by Koç et al. [14] which is; comparison of reaction time of hearing-impaired sedentary and hearing-impaired soccer players.

Bakır and Aydoğan [2] reports that in their study on visual impaired children; regular physical exercises shortened the auditory reaction time of children. As it is understood from this result which is, sportive exercise shortens reaction time, this study supports our study. It is known that the sport has contributed significantly to the physical development, physical fitness characteristics and body composition of hearing-impaired children.

To sum up it was found that the exercise program which was done for 3 days a week for 8 weeks, enhanced the reaction performance of hearing-impaired students aged 11-14 years. Accordingly, at least 8 weeks of exercise programs that can be implemented under the supervision of a physical education teacher or coach can enhance their performances and enable them to harmonise themselves with Daily life tasks more easily by improving their reaction time performances.

\section{References}

1. Anson, J.G. Effects of moment of inertia on simple reaction time. Journal of Motor Behavior, 21(1), 60-71., (1989).

2. Bakır, S., Aydoğan, H. 12-14 yaş grubu Gençlerbirliği Spor Kulübü sporcuları ile spor yapan ve yapmayan görme engelli öğrencilerinin işitsel basit reaksiyon zamanlarının 
karşılaştırılması. Selçuk Üniversitesi Beden Eğitimi ve Spor Bilimleri Dergisi, 13; 151160., (2011).

3. Bjorklund, R.A. Reaction time and movement time measured in keypress and a keyrealese condition. Perceptual and Motor Skill. 72, 663-673., (1991).

4. Bompa, T.O. Antrenman Kuramı ve Yöntemi. Keskin İ., Tuner A.B. (Çeviren), 1. Bask1, Ankara: Bağırgan Yayınevi, 357- 455., (1988).

5. Cağlar, Ö., Uludağ, A.H., Sepetci, T., \& Çalışkan, E. Evaluation of physical fitness parameters of hearing impaired adolescents who are active and non-active in sports. Turkish Journal of Sport and Exercise, 15(2); 38-44., (2013).

6. Ciğerci, A.E., Aksen, P, Cicioğlu, İ. \& Günay, M. 9-15 Yaş Grubu İșitme Engelli ve İșitme Engelli Olmayan Öğrencilerin Bazı Fizyolojik ve Motorik Özelliklerinin Değerlendirilmesi. Selçuk Üniversitesi Beden Eğitimi ve Spor Bilimleri Dergisi, 13,41., (2011).

7. Çolakoğlu, M., Tiryaki, Ş., \& Moralı, S. Konsantrasyon çalışmalarının reaksiyon zamanı üzerine etkisi, Hacettepe Üniversitesi Spor Bilimleri Dergisi, 4, 32-47, (1993).

8. Dowdy, B.D., Cureton, K.J., Duval, H.P., \& Ouzis, G.H. Effects of Aerobic Dance on Physical Quark Capacity, Cardiovascular Function and Boy Composition of Middle Aged Women, Research Quarterly for Exercise and Sport, 56,(3) 227-233., (1985).

9. Elmacı, S., Gürpınar, D., Erdinç., T., İşleğen Ertat, A., Durusoy, F. \& Gediz, A., Sedanter şahıslarda egzersizle kilo kaybının bazı kardiak risk faktörlerine etkisi, IV. Spor Hekimliği Kongresi, Bildiri Kitabı 17-19 Eylül, ss:263., (1993).

10.Groves, R. (1973). Relationship of Reaction Time and Movement Time in A Gross Motor skill. Perceptual and Motor Skills, 36: 453-454., (1973).

11. Jokela, J, \& Erai P. Reaction and Movement Times in Men of Different Ages Perceptial and Motor Skills USA., 63,111-124, (1986).

12. Karagöz, Ş. 8-10 yaş arası çocuklarda 12 haftalık tenis antrenmanlarının görsel ve işitsel reaksiyon zamanına etkisinin incelenmesi. Afyon Kocatepe Üniversitesi Sağlik Bilimleri Enstitüsü. Yüksek Lisans Tezi. 42-51, (2008).

13. Keskinkılıç, B., Yardım, N, \& Vardar, C. Türkiye fiziksel aktivite rehberi; engellilerde fiziksel aktivite; Kuban Matbaacılık ve Yayıncılık, Ankara, 26-31, (2014).

14. Koç, H., Tekin, A., Sitti, S., \& Akçakoyun, F. İşitme engelli sedanterler ile futbolcuların reaksiyon zamanının karşılaştırılması. Selçuk Üniversitesi Beden Eğitimi ve Spor Bilim Dergisi, 13 (3), 364-367, (2011).

15. Nöcker, J. Physiyological der Leibesungen, Ferdinand Enke Verlag, Stuttgard, 262., (1971)

16. O'Connell, M. The effect of brailling and physical guidance on the self-efficacy of children who are blind. Unpublished master's thesis: State University of New York College at Brockport, NY., (2000).

17. Rosenbaum, D.A.Human Motor Control Psyiological Foundations Acedemic Pres., London. (1991).

18. Rudisill, M.E., \& Thoole, T. The effect of pysical activity programme on reaction time an movement time for the older adult. Jour. Hum. Mow. Stu, 22, 205-212, (1992).

19. Schmidt, R.A. Motor Learning Anda Performance. Human Kinetics Pub. USA., (1991)

20. Sevim, Y. (2000). Antrenman Bilgisi. Ankara Nobel Yayınları, s: 112, (2000).

21. Şirinkan, A. 10-15 yaş işitme engelli öğrencilerde sportif eğitsel oyunların fiziksel gelişimlerine etkisinin araştırılması. Selçuk Üniversitesi Beden Eğitimi ve Spor Bilimleri Dergisi, 13 (3), 74-80, (2011).

22. Sullivan, S.J, \& Hayes, K.C. Changes in short and long latency strech reflexes prior to movement intitation. Brain Research, 139-143, (1987). 